\title{
PENGARUH PENGETAHUAN AKUNTANSI DAN KEPRIBADIAN PEGAWAI TERHADAP KUALITAS LAPORAN KEUANGAN PEMERINTAH DAERAH KABUPATEN SUMENEP
}

\author{
Winda Dwi Wardani ${ }^{1}$, Norsain ${ }^{2}$ \\ ${ }^{1,2)}$ Fakultas Ekonomi dan Bisnis Universitas Wiraraja \\ Email:Windadw1998@gmail.com ${ }^{1}$,norsain@wiraraja.ac.id ${ }^{2}$
}

\begin{abstract}
ABSTRAK
Laporan keuangan pemerintah yang berkualitas adalah laporan keuangan yang disajikan memenuhi karakteristik relevan, andal, dapat dibandingkan, dan dapat dipahami. Kabupaten Sumenep pada tahun 2017 dan 2018 memperoleh Opini Wajar Tanpa Pengecualian dari BPK. Akan tetapi ada catatan tambahan terkait dengan pengetahuan akuntansi dan kepribadian. Oleh karena itu, penelitian ini bertujuan Untuk menguji dan menganalisis pengaruh pengetahuan akuntansi dan kepribadian pegawai secara bersama-sama terhadap kualitas laporan keuangan pemerintah daerah kabupaten sumenep. Adapun populasi yang akan menjadi objek dalam penelitian ini adalah OPD di Kabupaten Sumenep. Teknik pengambilan sampel yaitu menggunakan purposive sampling. Jadi jumlah sampel dalam penelitia ini yaitu sebanyak 100 orang responden. Teknik pengumpulan data dilakukan dengan mengajukan kuisioner, hal ini dilakukan untuk memperoleh data dengan mengajukan sejumlah daftar pertanyaan kepada responden. Hasil penelitian ini menunjukkan bahwa, Pengetahuan Akuntansi berpengaruh terhadap Kualitas Laporan Keuangan Pemerintah Daerah, kepribadian pegawai berpengaruh terhadap Kualitas Laporan Keuangan Pemerintah Daerah, serta Pengetahuan Akuntansi dan kepribadian pegawai berpengaruh terhadap Kualitas Laporan Keuangan Pemerintah Daerah .
\end{abstract}

Kata Kunci : Pengetahuan Akuntansi, Kepribadian Pegawai, Kualitas Laporan Keuangan, Pemerintah Daerah 


\section{INTRODUCTION}

Pelayanan kepada masyarakat merupakan tuntutan dari pelaksanaan ekonomi daerah. Bentuk pelayanan yang dapat diberikan adalah dengan memberikan informasi laporan keuangan yang trasparan dan akuntabel. Laporan keuangan yang berkualitas dapat dihasilkan dengan adanya sumber daya manusia yang kompeten dan memiliki pengetahuan akuntansi. Unsur relevan, andal, dapat dibandingkan, dan dapat dipahami akan terpenuhi apabila laporan keuangan tersebut dikerjakan oleh sumber daya manusia yang ahli dibidang keuangan. Oleh karena itu dalam pemerintah daerah dibutuhkan sumber daya manusia yang memiliki pengetahuan dibidang akuntansi. Selain itu, kepribadian seseorang juga berpperan penting dalam proses penyajian laporan keuangan. Kepribadian adalah seluruh konsep atau pengetahuan yang abstrak tentang bagaimana menyebarkan sumber daya yang ada. Ada hubungan antara pengaruh pengetahuan dan kepribadian pegawai yaitu selain membutuhkan sumber daya manusia yang memiliki pengetahuan dibidang akuntansi, maka untuk menyajikan laporan keuangan yang berkualitas juga dibutuhkan kepribadian pegawai yang kompeten. Kepribadia pegawai ditunjang oleh lamanya masa kerja pegawai, keterampilan dan kemampuan menguasai pekerjaan. Semakain berpengalaman seorang pegawai maka kemampuan untuk mengerjakan tugas-tugas yang ada akan terselesaikan dengan cepat dan baik.

Opini yang diberikan oleh Badan Pemeriksa Keuangan membuktikan bahwa laporan keuangan yang disajikan oleh Pemerintah Daerah Kabupaten Sumenep mengalami peningkatan dari tahun sebelumnya dan merupakan laporan keuangan yang berkualitas. Opini Wajar Tanpa
Pengecualian (WTP) membuktikan laporan yang disajikan telah memenuhi unsur relevan, anadal, dapat dibandingkan, dan dapat dipahami. Tetapi, jika dilihat dari berita web resmi BPK mengungkapkan bahwa opini WTP yang diperoleh masih memperoleh catatan-catatan tambahan.. Catatan-catatan tambahan tersebut disampaikan oleh Ayub Ismail Plt Kepala BPK Jatim, dia berharap agar yang memperoleh WTP tidak cepat puas dan selalu meningkatkan akuntabilitas yang baik dalam rangka pengelolaan keuangan negara. Adapun catatan-catatan yang menjadi sumber permasalahan yang terjadi adalah pengetahuan akuntansi dan kepribadian. Permasalahan yang berkaitan dengan pengetahuan akuntansi adalah bahwa setiap daerah kota / kabupaten sebaiknya merekrut tenaga kerja yang ahli dalam bidang akuntansi dan teknologi informasi, karena kedua bidang itu akan menunjang kualitas dari laporan keuangan .Sedangkan untuk yang masalah tentang kepribadian adalah pemerintah daerah merasa puas dan terlena dengan pengelolaan aset daerahnya dan tata niaganya menjadi tidak terurus dengan baik.

Kabupaten Sumenep merupakan 1 dari 17 kabupaten atau kota di jawa timur yang diberikan opini "wajar tanpa pengecualian" (WTP) oleh Badan Pemeriksa Keuangan (BPK) Provinsi jawa timur. Seperti yang diketahui, bahwa 2 tahun terakhir yaitu pada tahun 2017 dan tahun 2018 pemerintah daerah mendapat opini WTP. Melihat peningkatan Kabupaten Sumenep dari tahun ke tahun yang semakin membaik, peneliti memilih Kabupaten Sumenep menjadi objek penelitian untuk mengetahui lebih mendalam faktorfaktor apa saja yang mendorong Kabupaten Sumenep mengalami peningkatan dari tahun ke tahun. Salah satu faktor yang ingin peneliti teliti adalah apakah pengetahuan akuntansi dan kepribadian pegawai mempengaruhi 
kualitas laporan keuangan pemerintah daerah Kabupaten Sumenep.

\section{LITERATURE REVIEW}

\section{Laporan Keuangan Pemerintah}

\section{a. Jenis Laporan Keuangan} Pemerintah Daerah

Ada beberapa jenis laporan keuangan pemerintah yang dipersyaratkan didalam PP No.71 tahun 2010 tentang Standar Akuntansi Pemerintah (SAP) yaitu:

a. Laporan Posisi Keuangan

b. Laporan Realisasi Anggaran

c. Saldo Anggaran Lebih

d. Operasional

e. Laporan Perubahan Ekuitas

f. Laporan Arus Kas

g. Catatan Atas Laporan Keuangan

b. Manfaat Laporan Keuangan Daerah

1. Laporan keuangan pemerintah bermanfaat menyediakan informasi keuangan.

\section{Memperkirakan} pengambilan dan pengalokasian sumberdaya pada pencapaian tujuan operasional.

3. mengevaluasi kinerja manajemen dan organisasi.

4. untuk memonitor kinerja

\section{c. Kualitas Laporan Keuangan}

\section{Pemerintah Daerah}

karakteristik kualitatif laporan keuangan :

1. Relevan

- Memiliki manfaat prediktif .

2. Tepat waktu

- Lengkap

3. Andal

Informasi yang andal memenuhi karakteristik:

- Penyajian jujur.

- Dapat diverifikasi (verifiability).

- Netralitas.
4. Dapat dibandingkan

5. Dapat dipahami

\section{Pengetahuan Akuntansi}

Pengetahuan Akuntansi adalah pengetahuan tentang segala hal yang berkaitan dengan proses transaksi,atau segala aktivitas yang berkaitan dengan laporan keuangan .

\section{Kepribadian Pegawai}

Kepribadian adalah cara seseorang dalam menjalani kehidupan atau tingkah laku yang dipraktikkan dalam bentuk sikap, watak, nilai kepercayaan, motif dan umunya definisi tersebut tergantung siapa saja yang mendefinisikannya

\section{METHODS}

Jenis penelitian menggunakan data kuantitatif dengan jenis penelitian korelasional (korelational research), yang mana tujuannnya mengetahui korelasi antara pengetahuan akuntansi dan kepribadian pegawai. Tempat dan waktu penelitian yang dilakukan oleh peneliti adalah Kantor Pemerintah Daerah Kabupaten Sumenep, yang beralamat di JL. Doktor Cipto Mangunkusomo No.1, Gudang, Kolor. Waktu penelitian akan dilaksanakan pada tanggal 15 januari 2020 hingga selesai. Adapun populasi yang akan menjadi objek dalam penelitian ini adalah OPD di Kabupaten Sumenep, yakni sebanyak 36 kantor OPD. Dari dari 36 OPD, dalam menentukan sampel tersebut peneliti menetapkan 25 kantor OPD. Dari 25 kantor OPD akan diambil 4orang. Jadi total sampel dalam penelitia ini yaitu sebanyak 100 orang responden, yang didapat dari 25 (kantor ODP) X 4 orang (sekretaris,kasubbag keuangan, staff kasubbag keuangan, dan kasubbag kepegawaian). Teknik pengumpulan data dilakukan dengan mengajukan kuisioner. Dan 
teknik analisis data yang digunakan dengan suatu instrumen yaitu berupa kuesioner dengan pengukuran variabel menggunakan skala likert. Peneliti menggunakan 5 jawaban atas setiap instrumen : "sangat setuju", "setuju", "ragu-ragu", "tidak setuju", dan "sangat tidak setuju".

\section{RESULTS AND DISCUSSIONS}

Penelitian ini menggunakan uji statistik yakni yang berupa uji regresi linier berganda, dengan variabel bebas pengetahuan akuntansi dan kepribadian pegawai serta kualitas laporan laporan keuangan sebagai variabel terikat. Berdasarkan hasil analisis data yang dilakukan, dan melalui item pertanyaan yang dilakukan untuk mengumpulkan data ini, jawaban responden atas semua item pertanyaan yang ada sudah valid dan reliabel. Selain itu, semua variabel variabel yang digunakan dalam penelitian ini juga reliabel, normal, linier, tidak ada gejala multikolinieritas,

autokorelasi, heteroskedastisitas.

\section{a) Pengaruh Pengetahuan Akuntansi terhadap Kualitas Laporan Keuangan Pemerintah Daerah}

Dilihat dari hasil uji pada tabel uji simultan (uji f) dan dan pada uji parsial ( uji t), Berdasarkan hasil uji hipotesis pertama, H1 menunjukkan nilai $f$ dengan memiliki kemungkinan kesalahan yaitu 0,000, sedangkan nilai t yaitu sebesar 10.861 dan memiliki kemungkinan kesalahan yaitu 0,000, karena nilai dari kedua uji tersebut nilai kemungkinan tejadinya kesalahan yaitu kurang dari 0,05 maka berarti hipotesis pertama diterima, dengan demikian pengetahuan akuntansi berpengaruh terhadap kualitas laporan keuangan pemerintah daerah kabupaten sumenep. Hal ini dibuktikan dengan daftar pertanyaan pada variabel $\mathrm{X} 1$ yaitu pengetahuan akuntansi yang disebarkan kepada 100 responden dengan jumlah pertanyaan yaitu sebanyak 9 pertanyaan, yang mana jawaban terbanyak atas pertanyaan tersebut yaitu "Setuju" dengan jumlah 589 jawaban responden "Setuju".

Menurut Niswonger (1996) dalam Siregar ( 2009) "pengetahuan akuntansi dapat didefinisikan sebagai seperangkat ilmu tentang informasi yang menghasilkan laporan keuangan kepada pihak yang berkepentingan mengenai aktivitas ekonomi dan kondisi perusahaan". Apabila pihak yang berkepentingan dalam perusahaan tersebut memiliki pengetahuan akuntansi yang baik, tentu mereka akan dapat menjalankan perusahaannya dengan baik dan mampu mendorong perusahaan yang dikelola menjadi perusahaan yang lebih maju. Seperangkat ilmu tentang infomasi dapat diperoleh melalui penguasaanya melului sejumlah pengetahuan akuntansi yang baik, entah itu yang berhubungan dengan aktivitas ekonomi dan kondisi perusahaan.

Akuntansi dapat membantu seseorang dalam memecahkan persoalan dan permasalahan dalam pengambilan keputusan, baik yang berhubungan dengan proses pencatatan, pengklasifikasian, dan berbagai aktivitas yang berhubungan dengan keluar masuknya uang. Peraturan pemerintah No. 71 tahun 2010 tentang SAP terdapat indikator yang harus dipenuhi dalam laporan keuangan yang meliputi syarat relevan, andal, dapat dibandingkan , dan dapat dipahami. Agar semua itu tercapai, maka perlu suatu pengetahuan akuntansi yang memadai agar kualitas dalam laporan keuangan bisa terpenuhi.

Hasil penelitian ini sama dengan penelitian yang dilakukan oleh Wildan Taufik Baihaqi, dkk (2019) yang menyatakan bahwa pengetahuan akuntansi pelaku usaha berpengaruh terhadap kualitas 
laporan keuangan UMKM di kabupaten banjarnegara. Berdasakan penelitian ini dan berdasarkan penelitian sebelumnya, dapat diambil kesimpulan bahwa semakin meningkat pengetahuan akuntansi, maka akan meningkatkan kualitas laporan keuangan.

\section{b) Pengaruh Kepribadian Pegawai terhadap Kualitas Laporan Keuangan Pemerintah Daerah}

Hipotesis kedua yaitu kepribadian pegawai berpengaruh terhadap kualitas laporan keuangan pemerintah daerah Kabupaten Sumenep ( studi OPD Pemerintah Daerah Kabupaten Sumenep). Dapat diambil kesimpulan yaitu semakin tinggi kepribadian yang dimiliki oleh seorang pegawai, maka akan dapat meningkatkan laporan keuangan yang baik atau berkualitas.

Berdasarkan hasil uji hipotesis kedua, $\mathrm{H} 2$ menunjukkan nilai $\mathrm{f}$ dengan kemungkinan terjadinya kesalahan yaitu sebesar 0,000, sedangkan nilai $\mathrm{t}$ yaitu sebesar 2,689 dan kemungkinan terjadinya kesalahan yaitu sebesar 0,008, karena nilai kemungkinan terjadinya kesalahan kurang dari 0,1 yaitu 0,008 kurang dari 0,05 maka berarti hipotesis kedua diterima, dengan demikian kepribadian pegawai berpengaruh terhadap kualitas laporan keuangan pemerintah daerah kabupaten sumenep. Hal ini dibuktikan dengan daftar pertanyaan pada variabel X2 yaitu kepribadian pegawai yang disebarkan kepada 100 responden dengan jumlah pertanyaan yaitu sebanyak 6 pertanyaan, yang mana jawaban terbanyak atas pertanyaan tersebut yaitu jawaban "Setuju" dengan jumlah 374 jawaban responden "Setuju".
Kepribadian pegawai berpengaruh terhadap kualitas laporan keuangan Pemerintah Daerah Kabupaten Sumenep, dan kebanyakan dari responden yang diteliti telah menunjukkan kepribadian yang baik, contohnya : responden memberi peluang besar bagi peneliti yang meminta izin dalam melaksanakan penelitian, responden mengarahkan alur dalam melakukan sebuah penelitian, dan responden siap melayani serta membantu peneliti dalam mendapatkan berbagai informasi yang diperlukan.

Menurut Ika ( 2011 ) “ kepribadian merupakan cara hidup atau gaya keseluruhan tingkah laku individu yang ditunjukkan dalam bentuk sikap, watak, nilai kepercayaan, motif dan sebagainya". Kepribadian merupakan ciri khusus dan pola watak yang dimilikioleh seseorang. Kepribadian merupakan penentu dalam laporan keuangan, karena dengan meningkatkan kepribadian yang baik, kejujuran, keuletan, tanggung jawab yang penuh maka laporan keuangan juga akan dapat dipertanggungjawabkan. Sikap seorang pegawai harus mencerminkan perilaku yang positif sehingga dalam melakukan pekerjaannya pegawai akan menanamkan perilaku baik. Adapun watak yang melekat dalam diri seorang pegawai akan mampu menghasilkan laporan keuangan yang dapat dipertanggung jawabkan. Seorang pegawai yang memiliki nilai kepercayaan yang tinggi akan senantiasa percaya diri terhadap setiap pekerjaan yang telah dilakukan.

Hasil penelitian ini sejalan dengan penelitian yang dilakukan oleh Susan Triswati (2019) bahwa kepribadian 
berpengaruh terhadap kualitas laporan keuangan pemerintah daerah kabupaten banjarnegara.ini dapat disimpulkan bahwa semakin baik kepribadian yang dimiliki seseorang, maka akan meningkatkan kualitas laporan keuangan.

\section{c) Pengaruh Pengetahuan Akuntansi dan Kepribadian Pegawai terhadap Kualitas Laporan Keuangan Pemerintah Daerah Kabupaten Sumenep}

Hipotesis ketiga yaitu pengetahuan akuntansi dan kepribadian pegawai berpengaruh terhadap kualitas laporan keuangan pemerintah daerah Kabupaten Sumenep ( studi OPD Kabupaten Sumenep. Artinya semakin tinggi pengetahuan akuntansi dan kepribadian pegawai, maka akan menghasilkan laporan keuangan yang berkualitas.

Berdasarkan hasil uji hipotesis ketiga, H3 menunjukkan nilai $f$ yaitu sebesar 71.282 dengan memiliki kemungkinan kesalahan yaitu 0,000, karena nilai dari uji tersebut kemungkinan terjadi kesalahannya kurang dari 0,05 maka berarti hipotesis ketiga diterima, dengan demikian pengetahuan akuntansi dan kepribadian pegawai secara simultan berpengaruh terhadap kualitas laporan keuangan pemerintah daerah kabupaten sumenep. Hal ini dibuktikan dengan daftar pertanyaan pada variabel X1 yaitu pengetahuan akuntansi dan variabel X2 yaitu kepribadian pegawai yang disebarkan kepada 100 responden dengan jumlah pertanyaan variabel X1 (pengetahuan akuntansi) sebanyak 9 pertanyaan dan variabel X2 (kepribadian pegawai) sebanyak 6 pertanyaan, yang mana jawaban terbanyak atas pertanyaan dari kedua variabel tersebut yaitu "Setuju" dengan jumlah 589 dan 374 jawaban responden "Setuju".

Pengetahuan akuntansi akan dapat menentukan kualitas dari suatu laporan keuangan, karena dengan pengetahuan yang memadai tentang akuntansi,seseorang dapat dengan mudah menyelesaikan pekerjaannya dengan baik, entah itu yang berhubungan dengan proses pencatatan, pengklasifikasian dan sebagainya. Jika seseorang itu sudah memiliki pengetahuan yang cukup tentang akuntansi, tentu akan paham betul alur dari akuntansi, sehingga kemungkinan terjadinya kesalahan akan dapat dihindari.

Kepribadian pegawai juga jadi penentu dalam laporan keuangan, dengan kepribadian yang baik, tentu akan dapat menghasilkan laporan keuangan yang berkualitas, untuk itu dalam membuat laporan keuangan yang berkualitas dibutuhkan kepribadian yang baik, yang menjunjung tinggi nilai kejujuran, keuletan, serta ketelitian.

Menurut Mahmudi dalam Razanisa Wilfa (2016) "Tujuan umum dari laporan keuangan adalah menyajikan informasi mengenai posisi keuangan, realisasi anggaran, arus kas dan kinerja suatu entitas pelaporan". Laporan keuangan sangat penting, karena dengan berbagai informasi yang didapat itu akan dijadikan sebuah pertimbangan dalam pengambilan keputusan .Untuk dijadikan suatu pertimbangan dalam pengambilan keputusan, maka laporan keuangan tersebut harus masuk dalam kategori berkualitas.

\section{CONCLUSIONS}

a. Pengetahuan Akuntansi berpengaruh terhadap Kualitas Laporan Keuangan Pemerintah Daerah Kabupaten Sumenep. 
Hal ini ditunjukkan dari hasil pengujian parsial dimana nilai kemungkinan terjadi kesalahan adalah $<0,05$ yaitu $0,000<0,5$. Pengetahuan akuntansi berpengaruh terhadap kualitas laporan keuangan pemerintah daerah kabupaten sumenep. Hal ini berarti bahwa pengetahuan akuntansi dapat meningkatkan kualitas laporan keuangan.

b. Kepribadian Pegawai berpengaruh terhadap Kualitas Laporan Keuangan Pemerintah Daerah Kabupaten Sumenep

Hal ini ditunjukkan dari hasil pengujian parsial dimana nilai kemungkinan terjadinya kesalahan adalah $<0,05$ yaitu $0,000<0,05$. Kepribadian pegawai berpengaruh terhadap kualitas laporan keuangan pemerintah daerah kabupaten sumenep. Hal ini berarti bahwa Kepribadian pegawai dapat meningkatkan kualitas laporan keuangan.

c. Pengetahuan Akuntansi dan Kepribadian Pegawai berpengaruh terhadap Kualitas Laporan Keuangan Pemerintah Daerah Kabupaten Sumenep

Hal ini ditunjukkan dari hasil pengujian secara bersama - sama (Simultan) dimana nilai kemungkinan terjadinya kesalahan adalah $<0,1$ yaitu $0,000<0,05$. Hal ini berarti bahwa pengetahuan akuntansi dan kepribadian pegawai secara simultan berpengaruh signifikan terhadap kualitas laporan keuangan pemerintah daerah kabupaten sumenep.
Selain itu peneliti juga memberikan saran diantaranya adalah

1. Bagi OPD (Organisasi Perangkat Daerah) Pemerintah Daerah Kabupaten Sumenep.

a. Sebaiknya seluruh OPD lebih meningkatkan pengetahuan akuntansi dengan cara membaca literatur serta mengikuti kursus.

b. Senantiasa menanamkan kepribadian yang baik.

2. Bagi Peneliti Selanjutnya

a. Memperluas wilayah penelitian, yang mana objek tidak hanya di satu kota melainkan di beberapa kota atau provnsi.

b. Menambah variabel bebas, seperti: pengalaman, usia, dan lain-lain.

\section{REFERENCES}
Allport \& Cattell, (1992). The Big Five Personality . Jurnal pengaruh pengetahuan akuntansi dan kepribadian wirausaha.

Peraturan pemerintah Nomor 71 tahun 2010 tentang standar akuntansi pemerintahan. (2010). Jakarta : Sekretariat Negara Republik Indonesia.

Sari., Ni Putu,. Y.M.A. dan Sujana.E. . (2014). Pengaruh pemahaman standar akuntansi pemerintah (SAP), pemanfaatan sistem informasi akuntansi keuangan daerah terhadap kualitas 
laporan keuangan pemerintah daerah ( Study kasus pada dinas - dinas pemerintah di kabupaten jemberana).ejuournal SI Akuntansi Universitas Pendidikan Ganesha ( Vol.2.No.1).

Sugiono. Prof Dr. (2017). Metode kuantitatif dan kualitatif. Penerbit Salemba Empat.

Triswati, Susan. (2019). Pengaruh Latar Belakang Pendidikan, Kepribadian Ihsan dan Pengendalian Internal Terhadap Kualitas Laporan Keuangan. Skripsi Universitas Islam Negeri Walisongo. Semarang.

Undang-Undang Nomor 12 Tahun 2003 tentang keuangan negar 
Journal of Accounting and Financial Issue ISSN : 2775-4642 (online)

Volume 1, Nomor 2, Oktober 2020 